\title{
Desulfacinum infernum gen. nov., sp. nov., a Thermophilic Sulfate-Reducing Bacterium from a Petroleum Reservoir
}

\author{
GAVIN N. REES, ${ }^{1 *}$ GINO S. GRASSIA, ${ }^{1}$ ALAN J. SHEEHY, ${ }^{1}$ PREM P. DWIVEDI, ${ }^{2}$ \\ AND BHARAT K. C. PATEL ${ }^{2}$ \\ Microbiology Research Unit, Faculty of Applied Science, University of Canberra, Belconnen, ACT 2616, ${ }^{1}$ and \\ Faculty of Science and Technology, Griffith University, Nathan, Brisbane, Queensland $4111,{ }^{2}$ Australia
}

\begin{abstract}
A thermophilic sulfate-reducing bacterium, Desulfacinum infernum, is described. This bacterium was isolated from produced formation water from a North Sea petroleum reservoir. In liquid culture, the cells are oval, 1.5 by 2.5 to $3 \mu \mathrm{m}$, nonmotile and gram negative. Spore formation has not been observed. Growth occurs at temperatures ranging from 40 to $65^{\circ} \mathrm{C}$, with optimum growth occurring at $60^{\circ} \mathrm{C}$, and at levels of salinity ranging from 0 to $50 \mathrm{~g}$ of $\mathrm{NaCl}$ per liter, with optimum growth occurring in the presence of $10 \mathrm{~g}$ of $\mathrm{NaCl}$ per liter. $D$. infernum grows on a range of organic acids, including formate, acetate, butyrate, and palmitate, and alcohols. $D$. infernum can grow autotrophically with $\mathrm{H}_{2}$. A vitamin supplement is required for growth. Sulfite and thiosulfate are used as electron acceptors. Sulfur and nitrate are not reduced. The DNA base composition is $64 \mathrm{~mol} \% \mathrm{G}+\mathrm{C}$. Phylogenetically, $D$. infernum clusters with members of the delta subdivision of the Proteobacteria. Its closest relatives are Syntrophobacter wolinii (level of similarity, 90.6\%) and Desulfomonile tiedjei (level of similarity, 87.1\%).
\end{abstract}

Sulfate-reducing bacterial activity in petroleum reservoirs often is initiated through the introduction of water that is injected to improve oil recovery. This bacterial activity results in the production and accumulation of hydrogen sulfide. Crude oil containing significant levels of hydrogen sulfide is regarded as soured and has greatly reduced commercial value because of increased refining and processing costs. Hydrogen sulfide also has been recognized as a cause of corrosion damage in structures used for oil recovery and storage and as a cause of blockage of formation strata by iron sulfide, resulting in reduced oil production. In addition, hydrogen sulfide is an occupational health and safety hazard which has resulted in death of oil industry workers (2). The problems resulting from hydrogen sulfide production are believed to be primarily caused by introduced sulfate-reducing bacteria (17). However, recent evidence suggests that indigenous sulfate-reducing bacteria may be involved in souring (36).

An understanding of the ecology of sulfate-reducing bacteria is essential if the adverse effects associated with hydrogen sulfide formation are going to be controlled. In this pursuit, a number of sulfate-reducing bacteria have been isolated from petroleum reservoirs. These include thermophilic sulfate-reducing bacteria, such as Thermodesulfobacterium mobile (formerly Desulfovibrio thermophilus [34]), Desulfotomaculum spp. (25, 32), and Archaeoglobus spp. (39), and mesophilic sulfatereducing bacteria, such as Desulfovibrio spp. $(22,33)$, Desulfobacterium cetonicum (14), and "Desulfobacterium oleovorans" (1), as well as Desulfomicrobium baculatus and Desulfomicrobium apsheronum (35).

The target reservoir used in this study (Beatrice, United Kingdom, North Sea) has been injected with seawater as a routine oil recovery practice. This has created a temperature gradient $\left(40\right.$ to $115^{\circ} \mathrm{C}$ ) between the wells used to inject the seawater and the wells used to produce formation fluids. Continuous injection of seawater has created a cool zone around the injection wells which is expanding toward the

\footnotetext{
* Corresponding author. Fax: 616251 6361. Electronic mail address: Rees@science.canberra.edu.au.
}

producing wells. The temperature of the reservoir prior to the introduction of seawater was about $115^{\circ} \mathrm{C}$.

As part of an on-going study to investigate the microbial ecology of high-temperature petroleum reservoirs, a novel thermophilic, sulfate-reducing bacterium, strain $\mathrm{B} \alpha \mathrm{G} 1^{\mathrm{T}}$ ( $\mathrm{T}=$ type strain), was isolated from produced formation waters obtained from the Beatrice petroleum reservoir. In this paper we describe strain $\mathrm{B} \alpha \mathrm{G} 1^{\mathrm{T}}$.

\section{MATERIALS AND METHODS}

Bacterial strain. Strain $\mathrm{B} \alpha \mathrm{Gl}^{\mathrm{T}}$ was isolated from produced formation water collected directly from well A08(10) on the Beatrice field platform. The Beatrice oil field is located in the British sector of the North Sea near the coast of Scotland.

Media and culture conditions. Strain $B \alpha G 1^{\mathrm{T}}$ was enriched and maintained on Postgate medium B (30) supplemented with $20 \mathrm{~g}$ of $\mathrm{NaCl}$ per liter and the vitamin solution of Wolin et al. (45). Purification and physiological studies were carried out in bicarbonate-buffered, sulfide-reduced medium containing $20 \mathrm{~g}$ of $\mathrm{NaCl}$ per liter and $3 \mathrm{~g}$ of $\mathrm{MgCl}_{2} \cdot 6 \mathrm{H}_{2} \mathrm{O}$ g per liter (42), as well as trace element solution SL-10 (18) and either the vitamin solution of Wolin et al. or $0.1 \mathrm{~g}$ of yeast extract per liter. Media were prepared as described by Patel et al. (26) and then reduced after dispensing. Cultures were grown in screw-cap tubes or serum bottles fitted with butyl rubber septa. Substrate tests were carried out in medium supplemented with vitamins, and the preparations were incubated for 2 to 4 weeks. Carbon and energy sources were added to media from sterile stock solutions. Hydrocarbons were filter sterilized directly into culture media, and the bottles were inverted to reduce hydrocarbon contact with the septa. Selenite and tungstate trace element solutions (4) were added when aromatic compounds were used as carbon sources. Conditions for autotrophic growth were established by dispensing $20-\mathrm{ml}$ portions of medium supplemented with vitamins into $125-\mathrm{ml}$ serum bottles containing an $80 \% \mathrm{~N}_{2}-20 \% \mathrm{CO}_{2}$ headspace and overpressuring the medium with $1 \mathrm{~atm}(101.29 \mathrm{kPa})$ of $80 \% \mathrm{H}_{2}-20 \% \mathrm{CO}_{2}$. To confirm autotrophy, strain $\mathrm{B} \alpha \mathrm{G}^{\mathrm{T}}$ was subjected to three consecutive transfers (inoculum, $1 \%$ ) in medium by using the $\mathrm{H}_{2}-\mathrm{CO}_{2}$ and $\mathrm{N}_{2}-\mathrm{CO}_{2}$ conditions described above. Unless indicated otherwise, all cultures were incubated at $60^{\circ} \mathrm{C}$.

Isolation and purity checks. Enrichment cultures for sulfate-reducing bacteria were prepared by adding produced formation water to culture media. Enrichment cultures that produced sulfide were subcultured into agar shake dilution tubes ( $2 \mathrm{~g}$ of purified agar per liter), and colonies were removed and subcultured until a pure culture was obtained (42).

Purity was checked at 40,60 , and $75^{\circ} \mathrm{C}$ aerobically on nutrient agar plates (Oxoid) and anaerobically in thioglycolate broth (Difco). In addition, purity was confirmed microscopically by examining cultures growing in anaerobic mineral salts medium containing yeast extract $(1 \mathrm{~g} / \mathrm{liter})$, pyruvate $(10 \mathrm{mM})$, and glucose (10 $\mathrm{mM})$.

Cellular characterization. Gram-staining characteristics were determined by using the Hucker method as described by Doetsch (11) and $\mathrm{KOH}$ lysis (5). 


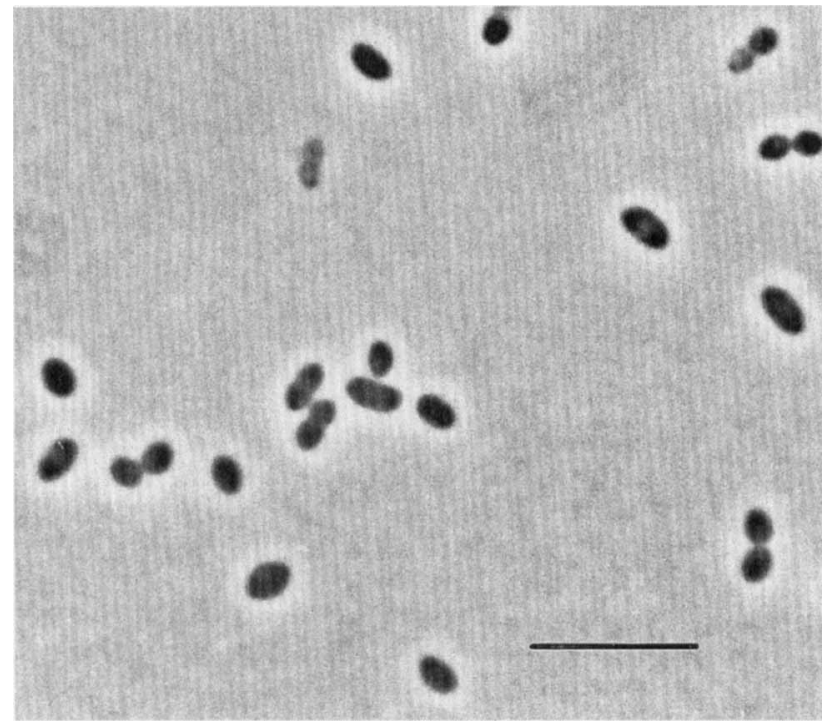

FIG. 1. Phase-contrast micrograph of strain $B \alpha G 1^{T}$. Bar $=10 \mu \mathrm{m}$.

Escherichia coli and Staphylococcus aureus were used as reference microorganisms. Negative stains and thin sections were prepared as described by Patel et al. (27). To facilitate detection of spores, cultures were subjected to heating at $95^{\circ} \mathrm{C}$ for 5 mins and then transferred to Postgate medium containing lactate and yeast extract. The resulting cultures were incubated for 4 weeks and examined periodically for sulfide production and growth. The Schaeffer-Fulton spore stain and Sudan black lipid stain (11) were used to characterize cell inclusions.

DNA was purified as described by Marmur (23), and the denaturation temperature was used to calculate the DNA base composition (24).

To detect desulfoviridin, cell extracts were examined for an absorption maximum at $630 \mathrm{~nm}$ (28). Cells also were examined for the presence of desulfoviridin following alkaline lysis (29).

$16 S$ rRNA sequence studies. Purification of genomic DNA and amplification and purification of the $16 \mathrm{~S}$ rRNA gene were carried out as described previously $(21,31)$. The purified PCR product was sequenced directly or cloned and sequenced as described previously (21). Sequences were determined with an ABI automated DNA sequencer by using a Prism dideoxy terminator cycle sequencing kit and the recommendations of the manufacturer (Applied Biosystems, Ltd.). The primers used for sequencing have been described previously (31).

Sequence editor ae2 (20) was used to align data obtained from the Ribosomal Database Project and GenBank and the 16S rRNA sequence of strain $B \alpha G 1^{T}$. Positions at which the sequence and alignment were uncertain were omitted from the analysis. Pairwise evolutionary distances based on 851 unambiguous nucleotides were computed by using the method of Jukes and Cantor (19). Dendrograms were constructed from the evolutionary distances by using the neighbor-joining method. A transversion analysis was performed by using the DNAPARS program. Tree topology was reexamined by using 100 bootstrapped data sets. The computer programs used to do this were SEQBOOT, DNADIST, FITCH, and CONSENSE. These programs are part of the PHYLIP version 3.51c software package (13). Programs available on TREECON (40) also were used to reexamine tree topology.

\section{RESULTS}

Isolation of thermophilic sulfate-reducing bacteria. Enrichment cultures containing lactate produced sulfide after 5 to 7 days of incubation at $60^{\circ} \mathrm{C}$. Microscopy revealed the presence of vibrios, as well as rod-shaped, spiral, and oval bacteria. The oval organism which dominated some enrichment cultures was purified by serial transfer and was designated strain $\mathrm{B} \alpha \mathrm{G} 1^{\mathrm{T}}$.

Cellular characteristics and nutrition. Strain $B \alpha G 1^{\mathrm{T}}$ cells were oval ( 1.5 by 2.5 to $3 \mu \mathrm{m}$ ) (Fig. 1). Motility was not observed, and flagella were not seen in negatively stained electron microscopy preparations. Gram staining and the $\mathrm{KOH}$ lysis test produced a gram-negative reaction. An examination of thin sections confirmed that this organism has a gram-negative type of cell wall.

Poorly refractile bodies were observed occasionally in sta- tionary-phase cultures. Cultures containing these cellular inclusions did not survive heating at $95^{\circ} \mathrm{C}$ for $5 \mathrm{~min}$ and did not react with the spore stain. The cellular inclusions did not react with the Sudan black stain for lipids and were not disrupted by centrifugation; thus, these inclusions were not gas vesicles.

Strain $\mathrm{B} \alpha \mathrm{G} 1^{\mathbf{T}}$ cells did not contain desulfoviridin. The DNA base composition was $64 \mathrm{~mol} \% \mathrm{G}+\mathrm{C}$.

Strain $B \alpha G 1^{\mathrm{T}}$ did not grow after three successive transfers in medium lacking vitamins. The vitamin requirement of strain $\mathrm{B} \alpha \mathrm{G} 1^{\mathrm{T}}$ could be replaced by $0.1 \mathrm{~g}$ of yeast extract per liter.

Physiological characteristics. Strain $\mathrm{B} \alpha \mathrm{G} 1^{\mathrm{T}}$ was able to use the following compounds as electron donors and carbon sources: formate $(10 \mathrm{mM})$, acetate $(10 \mathrm{mM})$, propionate $(10$ $\mathrm{mM}), n$-butyrate $(10 \mathrm{mM})$, isobutyrate $(10 \mathrm{mM}), n$-valerate $(5$ $\mathrm{mM})$, isovalerate $(5 \mathrm{mM})$, octanoate $(2.5 \mathrm{mM})$, decanoate $(0.5$ $\mathrm{mM})$, dodecanoate $(0.5 \mathrm{mM})$, hexadecanoate $(1 \mathrm{mM})$, octadecanoate $(1 \mathrm{mM})$, lactate $(10 \mathrm{mM})$, pyruvate $(10 \mathrm{mM})$, malate $(10 \mathrm{mM})$, fumarate $(5 \mathrm{mM})$, succinate $(5 \mathrm{mM})$, glycerol $(10$ $\mathrm{mM}$ ), ethanol (10 $\mathrm{mM})$, propanol $(10 \mathrm{mM})$, butanol $(10 \mathrm{mM})$, hexanol $(5 \mathrm{mM})$, and alanine $(10 \mathrm{mM})$. Good growth was maintained following subculture into carbon-free medium with a $\mathrm{H}_{2}-\mathrm{CO}_{2}$ headspace. No growth was detected after a second subculture into carbon-free medium with a $\mathrm{N}_{2}-\mathrm{CO}_{2}$ headspace.

Growth on octanoate, decanoate, and dodecanoate was dependent on substrate concentration. When octanoate was the substrate, growth was more rapid with $2.5 \mathrm{mM}$ octanoate than with $5 \mathrm{mM}$ octanoate. No growth occurred when $10 \mathrm{mM}$ octanoate was added to media. Growth on decanoate or dodecanoate did not occur when the concentration was greater than $0.5 \mathrm{mM}$.

Benzoate (5 mM), 3-chlorobenzoate (2 mM), 4-methoxybenzoate $(5 \mathrm{mM})$, cresol $(1 \mathrm{mM})$, citrate $(10 \mathrm{mM})$, glutamate $(10 \mathrm{mM})$, glucose $(5 \mathrm{mM})$, sucrose $(5 \mathrm{mM})$, fructose $(5 \mathrm{mM})$, dodecane $(1 \mathrm{mM})$, hexadecane $(1 \mathrm{mM})$, and crude oil (1 $\mathrm{ml} /$ liter) were not utilized.

Strain $\mathrm{B} \alpha \mathrm{G} 1^{\mathrm{T}}$ grew when pyruvate was present and sulfate was absent. No growth occurred on lactate, 4-methoxybenzoate, fumarate, ethanol, or glycerol in the absence of sulfate.

Sulfite and thiosulfate were used as alternative electron acceptors when either lactate, formate, or ethanol was used as a carbon and energy source. Sulfur and nitrate could not be used as electron acceptors.

Growth occurred at temperatures ranging from 40 to $65^{\circ} \mathrm{C}$, and optimum growth occurred at $60^{\circ} \mathrm{C}$. Growth occurred in media containing 0 to $50 \mathrm{~g}$ of $\mathrm{NaCl}$ per liter, and optimum growth occurred was in medium containing $10 \mathrm{~g}$ of $\mathrm{NaCl}$ per liter. Growth occurred at $\mathrm{pHs}$ ranging from of 6.6 to 8.4 , and the optimum $\mathrm{pH}$ was between 7.1 to 7.5 .

Growth on medium containing lactate and $20 \mathrm{mM}$ sulfate was markedly affected by the presence of molybdate. The generation times for strain $\mathrm{B} \alpha \mathrm{G} 1^{\mathrm{T}}$ during normal growth and growth in the presence of $0.01 \mathrm{mM}$ molybdate were 23 and 25 $\mathrm{h}$, respectively. Strain $\mathrm{B} \alpha \mathrm{G}^{\mathrm{T}}$ was inhibited completely by 0.03 $\mathrm{mM}$ molybdate. The inhibition of growth by molybdate is consistent with the finding that this organism is a sulfatereducing bacterium.

Phylogeny. A nearly complete sequence (1,544 bases) of the $16 \mathrm{~S}$ rRNA gene of strain $\mathrm{B} \alpha \mathrm{G} 1^{\mathrm{T}}$ was obtained by using 10 primers. This sequence (positions 8 to $1542 ; E$. coli numbering as described by Winker and Woese [44]) had all 70 of the required signature nucleotides and nucleotide pairs which indicate that an organism is a member of the bacterial domain (44). An analysis of the $16 \mathrm{~S}$ rRNA gene revealed that strain $\mathrm{B} \alpha \mathrm{G} 1^{\mathrm{T}}$ belongs in the delta subdivision of the Proteobacteria and that this organism is related to groups 2 to 7 of the sulfate-reducing bacteria $(7,15)$. Strain $\mathrm{B} \alpha \mathrm{G}^{\mathrm{T}}$ also possessed 
TABLE 1. Evolutionary distance matrix for strain $B \alpha G 1^{T}$ and related bacteria

\begin{tabular}{|c|c|c|c|c|c|c|c|c|c|c|c|c|c|c|}
\hline \multirow[b]{2}{*}{ Organism } & \multicolumn{14}{|c|}{ Evolutionary distance from: } \\
\hline & 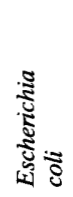 & 䨠氙 & 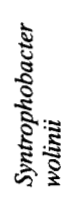 & 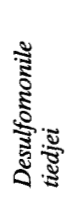 & 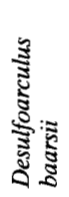 & 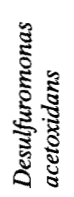 & 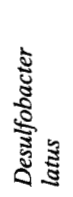 & 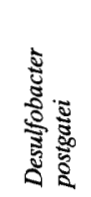 & 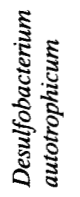 & 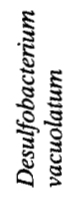 & 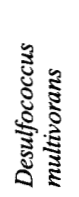 & 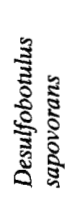 & 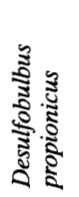 & 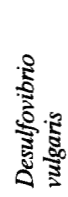 \\
\hline Strain $\mathrm{B} \alpha \mathrm{G} 1^{\mathrm{T}}$ & 25.5 & & & & & & & & & & & & & \\
\hline Syntrophobacter wolinii & 24.2 & 9.4 & & & & & & & & & & & & \\
\hline Desulfomonile tiedjei & 22.4 & 12.9 & 13.5 & & & & & & & & & & & \\
\hline Desulfoarculus baarsii & 21.8 & 15.3 & 14.5 & 13.3 & & & & & & & & & & \\
\hline Desulfuromonas acetoxidans & 21.8 & 13.6 & 15.2 & 13.3 & 16.3 & & & & & & & & & \\
\hline Desulfobacter latus & 25.2 & 19.5 & 19.6 & 20.1 & 19.5 & 17.8 & & & & & & & & \\
\hline Desulfobacter postgatei & 24.0 & 16.9 & 17.8 & 17.8 & 18.4 & 15.2 & 4.0 & & & & & & & \\
\hline $\begin{array}{l}\text { Desulfobacterium } \\
\text { autotrophicum }\end{array}$ & 23.6 & 17.2 & 16.5 & 16.3 & 18.3 & 14.0 & 11.5 & 111.1 & & & & & & \\
\hline $\begin{array}{l}\text { Desulfobacterium } \\
\text { vacuolatum }\end{array}$ & 26.5 & 18.6 & 20.1 & 18.7 & 18.9 & 17.2 & 13.1 & 12.1 & 6.8 & & & & & \\
\hline Desulfococcus multivorans & 21.6 & 14.5 & 15.0 & 14.0 & 13.8 & 16.1 & 15.3 & 14.2 & 12.9 & 13.8 & & & & \\
\hline Desulfobotulus sapovorans & 23.2 & 17.2 & 17.4 & 17.1 & 16.1 & 16.2 & 16.6 & 14.8 & 12.4 & 14.2 & 11.0 & & & \\
\hline Desulfobulbus propionicus & 22.6 & 14.3 & 15.9 & 15.5 & 17.2 & 13.6 & 18.1 & 15.8 & 16.8 & 19.5 & 17.2 & 18.3 & & \\
\hline Desulfovibrio vulgaris & 21.6 & 19.9 & 20.4 & 21.6 & 16.8 & 18.1 & 21.8 & 20.7 & 19.9 & 21.0 & 19.2 & 18.6 & 19.3 & \\
\hline Desulfomicrobium baculatus & 20.9 & 18.3 & 19.0 & 19.9 & 18.9 & 17.4 & 18.4 & 16.2 & 16.6 & 18.6 & 16.2 & 17.4 & 17.8 & 15.0 \\
\hline
\end{tabular}

the signature sequences which define the phylum Proteobacteria (37). The most closely related organisms were Syntrophobacter wolinii and Desulfomonile tiedjei (levels of similarity, 90.6 and $87.1 \%$, respectively) Strain $\mathrm{B} \alpha \mathrm{G} 1^{\mathrm{T}}$ was distantly related to members of other groups (Table 1). Relationships derived from sequence data are shown in Fig. 2.

The base composition of the 16S rRNA gene of strain $\mathrm{BaG} 1^{\mathrm{T}}$ was $58.7 \mathrm{~mol} \% \mathrm{G}+\mathrm{C}$; this value is similar to the values obtained for Syntrophobacter wolinii $(57.5 \mathrm{~mol} \% \mathrm{G}+\mathrm{C})$, Desulfoarculus baarsii (56 mol\% $\mathrm{G}+\mathrm{C}$ ), and Desulfomonile tiedjei $(55.3 \mathrm{~mol} \% \mathrm{G}+\mathrm{C})$. The average level of similarity between the $16 \mathrm{~S}$ rRNA $\mathrm{G}+\mathrm{C}$ content of strain $\mathrm{B} \alpha \mathrm{G} 1^{\mathrm{T}}$ and the $16 \mathrm{~S}$ rRNA $\mathrm{G}+\mathrm{C}$ contents of the other sulfate-reducing bacteria in Table 1 was only $52.5 \%$; consequently, a bias in tree construction can be introduced. No change in tree topology was observed when

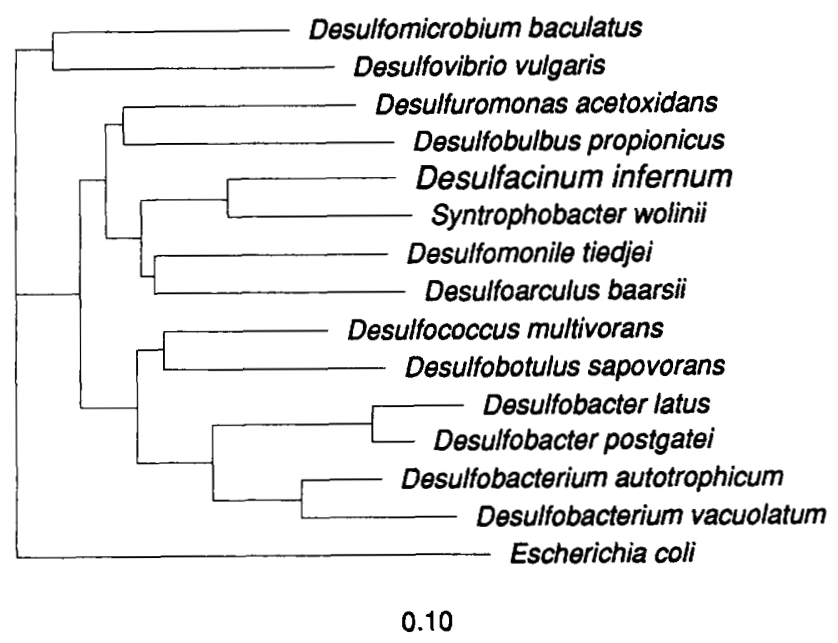

FIG. 2. Dendrogram indicating the position of strain $\mathrm{B \alpha G1} 1^{\mathrm{T}}$ among the sulfate-reducing bacteria belonging to the delta subdivision of the Proteobacteria. The dendrogram was derived from the distance matrix shown in Table 1. Scale bar $=10$ substitutions per 100 nucleotides. we used transversion analysis. In addition, a parsimony analysis produced the same tree topology. The bootstrap analysis revealed a robust relationship $(100 \%)$.

Two important differences between the 16S rRNA sequence of strain $\mathrm{B} \alpha \mathrm{G} 1^{\mathrm{T}}$ and the $16 \mathrm{~S}$ rRNA sequences of all other members of the delta subdivision of the Proteobacteria were (i) an absence of the common signature sequences in strain $\mathrm{B} \alpha \mathrm{G} 1^{\mathrm{T}}(8,9)$, and (ii) a difference in the higher-order structure at positions 179 to 190 (E. coli numbering of Winker and Woese [44]).

\section{DISCUSSION}

On the basis of $16 \mathrm{~S}$ rRNA sequence data, strain $\mathrm{B} \alpha \mathrm{G} 1^{\mathrm{T}}$ falls into the delta subdivision of the Proteobacteria and clusters with members of the family Desulfobacteriaceae (as proposed by Widdel and Bak [42]). The closest relatives of strain $\mathrm{B} \alpha \mathrm{G} 1^{\mathrm{T}}$ are Desulfomonile tiedjei (10) and Syntrophobacter wolinii (15). Previously described thermophilic sulfate reducers either branch near the root of the eubacterial tree $(16,43)$ or are members of the Archaea (38). There also are thermophilic members of the genus Desulfotomaculum which branch with the gram-positive line of eubacteria (41). In contrast, strain $\mathrm{B} \alpha \mathrm{G} 1^{\mathrm{T}}$ is related to mesophilic gram-negative sulfate-reducing bacteria (7) which belong to the delta subdivision of the Proteobacteria.

Strain $\mathrm{B} \alpha \mathrm{G} 1^{\mathrm{T}}$ was isolated by enrichment with lactate and could grow on a range of fatty acids, including acetate and propionate. Compounds such as acetate and propionate are known to occur in oil field waters (6) and therefore are more likely to be the substrates used by $\mathrm{B} \alpha \mathrm{G} 1^{\mathrm{T}}$ in situ.

Strain $\mathrm{B} \alpha \mathrm{G} 1^{\mathrm{T}}$ differs physiologically and morphologically from its closest phylogenetic relatives in several respects. Strain $\mathrm{B} \alpha \mathrm{G} 1^{\mathrm{T}}$ is thermophilic, whereas its relatives are mesophilic. It differs from Desulfomonile tiedjei by having a higher DNA $\mathrm{G}+\mathrm{C}$ content, by not producing desulfoviridin, by not having a "collared" morphology, and by not being able to use benzoate, demethylate methoxybenzoate, or dechlorinate 3-chlorobanzoate. Syntrophobacter wolinii originally was classified on the basis of its morphology and ability to grow only on 
propionate in syntrophic association with an $\mathrm{H}_{2}$-using organism (3). Since the original classification, Harmsen et al. have described a purified culture of Syntrophobacter wolinii that grows on pyruvate (15); the ability to oxidize propionate to acetate by using sulfate as an electron acceptor also has been reported (12). The metabolic capabilities of Syntrophobacter wolinii are not understood fully; however, physiologically this organism appears to differ significantly from strain $\mathrm{B} \alpha \mathrm{G} 1^{\mathrm{T}}$. Strain $\mathrm{B} \alpha \mathrm{G} 1^{\mathrm{T}}$ was similar to Desulfoarculus baarsii the following characteristics: DNA $\mathrm{G}+\mathrm{C}$ content, ability to use monocarboxylic acids with 3 to 18 carbon atoms, and absence of desulfoviridin. Strain $\mathrm{B} \alpha \mathrm{G}^{\mathrm{T}}$ differed from Desulfoarculus baarsii in its ability to grow autotrophically with $\mathrm{H}_{2}$ and its ability to use a range of dicarboxylic acids and alcohols as electron donors. On the basis of the results of phylogenetic analyses and physiological studies, we propose that strain $\mathrm{B} \alpha \mathrm{G} 1^{\mathrm{T}}$ represents a new species of a new genus. We propose the name Desulfacinum infernum gen. nov., sp. nov. for this organism.

Description of Desulfacinum gen. nov. Desulfacinum (De. sulf.a.ci'num. L. pref. de, from; L. n. sulfur, sulfur; L. n. acinum, a berry [especially a grape]; L. n. Desulfacinum, a berry-shaped sulfate-reducing bacterium). Oval cells which are nonmotile. Strict anaerobes which use sulfate as an electron acceptor; the sulfate is reduced to sulfide. Nutritionally versatile, oxidizing a number of organic acids and alcohols. The genus Desulfacinum belongs to the delta subunit of the Proteobacteria. The closest relatives are Syntrophobacter wolinii and the genus Desulfomonile.

Description of Desulfacinum infernum sp. nov. Desulfacinum infernum (in. fer' num. L. adj. infernum, that which is, or comes from, below, especially the lower world). Oval cells that are 1.5 by 2.5 to $3 \mu \mathrm{m}$. Nonmotile. Gram-negative type of cell wall structure. Vitamins are required for growth. Temperature range, 40 to $65^{\circ} \mathrm{C}$. Optimum growth occurs at $60^{\circ} \mathrm{C}$. $\mathrm{pH}$ range, 6.6 to 8.4 . The optimum $\mathrm{pH}$ is between 7.1 and 7.5. Salinity range, 0 to $50 \mathrm{~g}$ of $\mathrm{NaCl}$ per liter. Optimum growth occurs in the presence of $10 \mathrm{~g}$ of $\mathrm{NaCl}$ per liter. Formate, acetate, propionate, butyrate, isobutyrate, valerate, isovalerate, hexanoate, octanoate, decanoate, dodecanoate, hexadecanoate, octadecanoate, lactate, pyruvate, malate, fumarate, succinate, glycerol, ethanol, propanol, butanol, hexanol, and alanine are used as electron donors and carbon sources. Autotrophic growth occurs with $\mathrm{H}_{2}-\mathrm{CO}_{2}$. Benzoate, cresol, citrate, glutamate, glucose, sucrose, fructose, dodecane, and hexadecane are not used. Sulfate, sulfite, and thiosulfate are used as electron acceptors and are reduced to sulfide. DNA base composition, $64 \mathrm{~mol} \% \mathrm{G}+\mathrm{C}$ (as determined by thermal denaturation). The habitat is a high-temperature, seawater-flooded petroleum reservoir in the British sector of the North Sea.

The type strain is $B \alpha G 1$, which has been deposited in the Australian Collection of Microorganisms, University of Queensland, Brisbane, Australia, under accession number ACM 3991.

\section{ACKNOWLEDGMENTS}

This work was funded by Live Oil Services N.V., Melbourne, Australia.

We thank J. Bruce for technical assistance, The Australian National University and Griffith University for use of electron microscopy facilities, and the assistance of workers at British Petroleum Exploration (UK) for sample collection.

\section{REFERENCES}

1. Aeckersberg, F., F. Bak, and F. Widdel. 1991. Anaerobic oxidation of saturated hydrocarbons to $\mathrm{CO}_{2}$ by a new type of sulfate-reducing bacterium. Arch. Microbiol. 156:5-14.
2. Battersby, N. S., D. J. Stewart, and A. P. Sharma. 1985. Microbiological problems in the offshore oil and gas industries. J. Appl. Bacteriol. Symp. Suppl. 59:227S-235S.

3. Boone, D. R., and M. P. Bryant. 1980. Propionate-degrading bacterium, Syntrophobacter wolinii sp. nov., gen. nov., from methanogenic ecosystems. Appl. Environ. Microbiol. 40:626-632.

4. Brysch, K., C. Schneider, G. Fuchs, and F. Widdel. 1987. Lithoautotrophic growth of sulfate-reducing bacteria, and description of Desulfobacterium autotrophicum gen. nov., sp. nov. Arch. Microbiol. 148:264-274.

5. Buck, J. D. 1982 . Nonstaining (KOH) method for determination of Gram reactions of marine bacteria. Appl. Environ. Microbiol. 44:992-993.

6. Carothers, W. W., and Y. K. Kharaka. 1978. Aliphatic acid anions in oil-field waters-implications for the origin of natural gas. AAPG (Am. Assoc. Pet. Geol.) Bull. 62:2441-2453.

7. Devereux, R., M. Delaney, F. Widdel, and D. A. Stahl. 1989. Natural relationships among sulfate-reducing eubacteria. J. Bacteriol. 171:66896695 .

8. Devereux, R., S. H. He, C. L. Doyle, S. Orkland, D. A. Stahl, J. LeGall, and W. B. Whitman. 1990. Diversity and origin of Desulfovibrio species: phylogenetic definition of a family. J. Bacteriol. 172:3609-3619.

9. Devereux, R., M. D. Kane, J. Winfrey, and D. A. Stahl. 1992. Genus- and group-specific hybridization probes for determinative and environmental studies of sulfate-reducing bacteria. Syst. Appl. Microbiol. 15:601-609.

10. DeWeerd, K. A., L. Mandelco, R. S. Tanner, C. R. Woese, and J. M. Suflita. 1990. Desulfomonile tiedjei gen. nov. and sp. nov., a novel anaerobic, dehalogenating, sulfate-reducing bacterium. Arch. Microbiol. 154:23-30.

11. Doetsch, R. N. 1981. Determinative methods of light microscopy, p. 21-33. In P. Gerhardt, R. G. E. Murray, R. N. Costilow, E. W. Nester, W. A. Wood, N. R. Krieg, and G. B. Phillips (ed.), Manual of methods for general bacteriology. American Society for Microbiology, Washington, D.C.

12. Dörner, C. 1992. Ph.D thesis. Eberhard-Karls-Universität, Tübingen, Germany.

13. Felsenstein, J. 1993. PHYLIP (phylogenetic inference package) version 3.5.1. Department of Genetics, University of Washington, Seattle.

14. Galushko, A. S., and E. P. Rozanova. 1992. Desulfobacterium cetonicum sp. nov.: a sulfate-reducing bacterium which oxidizes fatty acids and ketones. Microbiology (Engl. Transl. Mikrobiologiya) 60:742-746.

15. Harmsen, H. J. M., B. Wullings, A. D. L. Akkermans, W. Ludwig, and A. J. M. Stams. 1993. Phylogenetic analysis of Syntrophobacter wolinii reveals a relationship with sulfate-reducing bacteria. Arch. Microbiol. 160:238-240.

16. Henry, E. A., R. Devereux, J. S. Maki, C. C. Gilmour, C. R. Woese, L. Mandelco, R. Schauder, C. C. Remsen, and R. Mitchell. 1994. Characterization of a new thermophilic sulfate-reducing bacterium, Thermodesulfovibrio yellowstonii, gen. nov. and sp. nov.: its phylogenetic relationship to Thermodesulfobacterium commune and their origins within the bacterial domain. Arch. Microbiol. 161:62-69.

17. Herbert, B. N., P. D. Gilbert, H. Stockdale, and R. J. Watkinson. 1985. Factors controlling the activity of sulphate-reducing bacteria in reservoirs during water injection. Proceedings of the Conference on "Offshore Europe '85." Soc. Petroleum Eng. SPE 13978/10:1-10.

18. Imhoff-Stuckle, D., and N. Pfennig. 1983. Isolation and characterization of a nicotinic acid-degrading sulfate-reducing bacterium, Desulfococcus niacini sp. nov. Arch. Microbiol. 136:194-198.

19. Jukes, T. H., and C. R. Cantor. 1969. Evolution of protein molecules, p. 21-132. In H. N. Munro (ed.), Mammalian protein metabolism, vol. 3. Academic Press, New York.

20. Larsen, N., G. J. Olsen, B. L. Maidak, M. J. McCaughey, R. Overbeek, T. J. Macke, T. L. Marsh, and C. R. Woese. 1993. The Ribosomal Database Project. Nucleic Acids Res. 21(Suppl.):3021-3023.

21. Love, C. A., B. K. C. Patel, P. D. Nichols, and E. Stackebrandt. 1993. Desulfotomaculum australicum, sp. nov., a thermophilic sulfate-reducing bacterium isolated from the great artesian basin of Australia. Syst. Appl. Microbiol. 16:244-251.

22. Magot, M., P. Caumette, J. M. Desperrier, R. Matheron, C. Dauga, F. Grimont, and L. Carreau. 1992. Desulfovibrio longus sp. nov., a sulfatereducing bacterium isolated from an oil-producing well. Int. J. Syst. Bacteriol. 42:398-403.

23. Marmur, M. 1961. A procedure for the isolation of deoxyribonucleic acid from microorganisms. J. Mol. Biol. 3:208-218.

24. Marmur, M., and P. Doty. 1962. Determination of the base composition of deoxyribonucleic acid from its thermal denaturation temperature. J. Mol. Biol. 5:109-118.

25. Nazina, T. N., and E. P. Rozanova. 1978. Thermophilic sulfate-reducing bacteria from oil strata. Microbiology (Engl. Transl. Mikrobiologiya) 47:113118.

26. Patel, B. K. C., H. W. Morgan, and R. M. Daniel. 1985. A simple and efficient method for preparing and dispensing anaerobic media. Biotechnol. Lett. 7:277-278.

27. Patel, B. K. C., H. W. Morgan, and R. M. Daniel. 1985. Fervidobacterium nodosum gen. nov. and spec. nov., a new chemoorganotrophic, caldoactive, anaerobic bacterium. Arch. Microbiol. 141:63-69.

28. Postgate, J. R. 1956. Cytochrome $c_{3}$ and desulphoviridin; pigments of the 
anaerobe Desulphovibrio desulphuricans. J. Gen. Microbiol. 14:545-572.

29. Postgate, J. R. 1959. A diagnostic reaction of Desulphovibrio desulphuricans. Nature (London) 183:481-482.

30. Postgate, J. R. 1979. The sulphate-reducing bacteria. Cambridge University Press, London.

31. Redburn, A. C., and B. K. C. Patel. 1993. Phylogenetic analysis of Desulfotomaculum thermobenzoicum using polymerase chain reaction-amplified $16 \mathrm{~S}$ rRNA-specific DNA. FEMS Microbiol. Lett. 113:81-86.

32. Rosnes, J. T., T. Torsvik, and T. Lien. 1991. Spore-forming thermophilic sulfate-reducing bacteria isolated from North Sea oil field waters. Appl. Environ. Microbiol. 57:2302-2307.

33. Rozanova, E. P., and A. I. Khudyakova. 1973. Sulfate-reducing bacteria from oil beds of the Apsheron. Microbiology (Engl. Transl. Mikrobiologiya) 42:115-118.

34. Rozanova, E. P., and A. I. Khudyakova. 1974. A new nonspore-forming thermophilic sulfate-reducing organism, Desulfovibrio thermophilus nov. sp. Microbiology (Engl. Transl. Mikrobiologiya) 43:908-912.

35. Rozanova, E. P., T. N. Nazina, and A. S. Galushko. 1988. Isolation of a new genus of sulfate-reducing bacteria and description of this genus, Desulfomicrobium apsheronum gen. nov., sp. nov. Microbiology (Engl. Transl. Mikrobiologiya) 57:514-520.

36. Scott, P. J. B., and M. Davies. 1993. Souring of new Irian Jaya wells traced to indigenous bacteria. Oil Gas J. 91:47-50.

37. Stackebrandt, E., R. G. E. Murray, and H. G. Trüper. 1988. Proteobacteria classis nov., a name for the phylogenetic taxon that includes the "purple bacteria and their relatives.” Int. J. Syst. Bacteriol. 38:321-325.
38. Stetter, K. O. 1988. Archaeoglobus fulgidus gen. nov., sp. nov.: a new taxon of extremely thermophilic archaebacteria. Syst. Appl. Microbiol. 10:172-173.

39. Stetter, K. O., R. Huber, E. Blöchl, M. Kurr, R. D. Eden, M. Flelder, H. Cash, and I. Vance. 1993. Hyperthermophilic archea are thriving in deep North sea and Alaskan oil reservoirs. Nature (London) 365:743-745.

40. Van de Peer, Y., and R. De Wachter. 1992. TREECON: a software package for the construction and drawing of evolutionary trees. CABIOS 9:117-182.

41. Widdel, F. 1992. The genus Desulfotomaculum, p. 1792-1799. In A. Balows, H. G. Trüper, M. Dworkin, W. Harder, and K. H. Schleifer (ed.), The prokaryotes. A handbook on the biology of bacteria: ecophysiology, isolation, identification, applications, 2nd ed. Springer-Verlag, New York.

42. Widdel, F., and F. Bak. 1992. Gram-negative mesophilic sulfate-reducing bacteria, p. 3352-3378. In A. Balows, H. G. Trüper, M. Dworkin, W. Harder, and K. H. Schleifer (ed.), The prokaryotes. A handbook on the biology of bacteria: ecophysiology, isolation, identification, applications, 2nd ed. Springer-Verlag, New York.

43. Widdel, F., and T. A. Hansen. 1992. The dissimilatory sulfate- and sulfurreducing bacteria, p. 583-624. In A. Balows, H. G. Trüper, M. Dworkin, W. Harder, and K. H. Schleifer (ed.), The prokaryotes. A handbook on the biology of bacteria: ecophysiology, isolation, identification, applications, 2nd ed. Springer-Verlag, New York.

44. Winker, S., and C. R. Woese. 1991. A definition of the domains Archaea, Bacteria and Eucarya in terms of small subunit ribosomal RNA characteristics. Syst. Appl. Microbiol. 14:305-310.

45. Wolin, E. A., M. J. Wolin, and R. S. Wolfe. 1963. Formation of methane by bacterial extracts. J. Biol. Chem. 238:2882-2886. 